\title{
Volvariella leucocalix (Pluteaceae), a new species from Brazilian semiarid region
}

\section{Sá $\mathrm{MCA}^{1}$ and Wartchow $\mathrm{F}^{2}$}

${ }^{1}$ Universidade Federal do Rio Grande do Norte, Programa de Pós-Graduação em Sistemática e Evolução, Campus Universitário, Lagoa Nova, CEP 59072-970 Natal, RN, BRAZIL. marianasa85@gmail.com.

${ }^{2}$ Universidade Federal da Paraíba, Departamento de Sistemática e Ecologia/CCEN, CEP 58051-970, João Pessoa, $P B, B R A Z I L$.

Sá MCA, Wartchow F 2016 - Volvariella leucocalix (Pluteaceae), a new species from Brazilian semiarid region. Mycosphere 7(1), 30-35, Doi 10.5943/mycosphere/7/1/3

\begin{abstract}
Volvariella leucocalix sp. nov. is a new record from Brazilian semiarid region. It is characterized macroscopically by the plane and shallowly umbonate and fuliginous brown, $26 \mathrm{~mm}$ in diam. pileus and white volva. Microscopically the basidiospores are ellipsoid to elongate, 5-5.6 $\times 2.6-3.6 \mu \mathrm{m}$, pleurocystidia fusoid-ventricose, $36-49 \times 6-11 \mu \mathrm{m}$ and pileipellis as a trichoderm with cylindric elements.
\end{abstract}

Key words - Agaricomycetes - neotropic - fungal diversity - taxonomy

\section{Introduction}

Volvariella Speg. sensu stricto is a cosmopolitan genus, recognized by the presence of saccate volva at the base of stipe, pink spore print, basidiospores smaller than $11 \mu \mathrm{m}$, bilateral inverse lamella trama and pileipellis as cutis or trichoderm with hyphae wider than $15 \mu \mathrm{m}$ and no gelatinous layer (Singer 1986, Justo et al. 2010). This genus [under the name Volvaria (Fr.) P. Kumm] was first described for Brazil by Rick (1907, 1919, 1920, 1938) and Theissen (1912). Later, Singer $(1953,1989)$ described other taxa of this genus. Recently new records were added to this group, with de Meijer (2001, 2006), Sobestiansky (2005) and Menolli \& Capelari (2008) in some Brazilian States. From the Northeast Brazil, the earliest record was given by Batista (1957) with Volvaria oswaldoi Bat. later combined to with Volvariella oswaldoi (Bat.) Putzke (1994 as 'osvaldoi') from Pernambuco. The most recent record of this genus was given by Wartchow (2009), who reported Volvariella cubensis (Murrill) Shaffer from this state.

The present paper describes a new species of Volvariella from the Brazilian semiarid region and we also provides drawings and taxonomic comparisons with similar taxa.

\section{Materials \& methods}

The basidiome was collected in a tropical wet mountain forest in Brazil known as 'brejo de altitude' and known as 'Mata do Pau-Ferro' $\left(06^{\circ} 58^{\prime} 12^{\prime \prime} \mathrm{S}\right.$ and $\left.35^{\circ} 42^{\prime} 15^{\prime \prime} \mathrm{W}\right)$, an area about 600 ha, altitude range up to 400-600 m (Barbosa et al. 2004, Andrade et al. 2006, Oliveira et al. 2006). Recent inventory reported 309 angiosperm taxa, with Rubiaceae, Malvaceae, Asteraceae, Convolvulaceae, Solanaceae and Fabaceae as the most diverse (Barbosa et al. 2004). For better view of the cells were studies using Congo red reagent and the basidiospores were measured in 
Melzer's reagent. Statistics are based on 30 basidiospores measured. Abbreviations include L(W) = basidiospore length (width) average from a single basidiome, $\mathrm{Q}=$ the length: width ratio range as determined from all measured basidiospores, and $\mathrm{Qm}=$ the $\mathrm{Q}$ value averaged from all basidiospores. The holotypus is deposited at JPB (Thiers, continuously updated).

\section{Taxonomy}

Volvariella leucocalix Sá \& Wartchow, sp. nov.

Figs. 1-8. MycoBank 815267

Facesoffungi number FoF 01833

Diagnosis - Plane and shallowly umbonate and fuliginous brown, $26 \mathrm{~mm}$ in diam. pileus, white volva, ellipsoid to elongate, 5-5.6 $\times 2.6-3.6 \mu \mathrm{m}$ basidiospores, fusoid-ventricose to lageniform pleurocystidia, 36-49 $\times 6-11 \mu \mathrm{m}$, and pileipellis as a trichoderm, composed of cylindrical elements.

Typus - BRAZIL, Paraíba State, Areia City, Parque Estadual da Mata do Pau-Ferro, Trilha do Cumbre, 16.vii.2013, F. Wartchow \& F.G.B. Pinheiro FW 39/2013 (JPB 61264 holotypus!).

Etymology - from Greek, 'leuco' (= whitish) and 'calix' (= cup). Name after whitish cuplike volva of the new species.

Pileus $26 \mathrm{~mm}$, plane, shallowly umbonate, fuliginous brown (65.br Black) at umbo then dark brown (62.d.gy.Br), fibrillose radially oriented striations toward margin; margin entire, not sulcate nor striate; context $1.5 \mathrm{~mm}$ thick at centre, gradually thinning, white. Lamellae free, subclose, pinkish (31 p.y Pink), $4 \mathrm{~mm}$ broad, edge entire, concolorous; lamellulae common with diverse lengths. Stipe $44 \times 2.5 \mathrm{~mm}$ ( $5 \mathrm{~mm}$ at the base), white, narrowing upward, smooth; context hollow at apex, solid bellow, white; volva to $7 \mathrm{~mm}$ high, white, smooth, cupulate with two lobes.

Basidiospores 5-5.6 $\times 2.6-3.6 \mu \mathrm{m},(\mathrm{L}=5.2 \mu \mathrm{m}, \mathrm{W}=3.1 \mu \mathrm{m}, \mathrm{Q}=(1.43-) 1.57-1.83(-2.00)$, Qm $=1.68 \mu \mathrm{m})$, ellipsoid to elongate, pinkish, thin-walled, inamyloid, with olive guttule in 3\% KOH. Basídia 19-28 × 6-9 $\mu \mathrm{m}$, clavate, with 4 sterigmata up to 1-4 $\mu \mathrm{m}$ high. Pleurocystidia $36-$ $49 \times 6-11 \mu \mathrm{m}$, fusoid-ventricose, sometimes short neck or thick and with an acute apex, thinwalled, hyaline in $3 \% \mathrm{KOH}$. Cheilocystidia $31-35 \times 6-10 \mu \mathrm{m}$, fusoid to fusoid-ventricose, thinwalled, hyaline in $3 \% \mathrm{KOH}$. Lamella trama compose of hyaline hyphae $2.6-5.1 \mu \mathrm{m}$ wide, thinwalled. Pileipellis as trichoderm, formed by septate/catenate hyphae ascending gradually, but not hymeniform, terminal elements cylindric 25-56 $(-83) \times 9-14 \mu \mathrm{m}$, yellowish in $3 \% \mathrm{KOH}$, smooth and thin-walled and hyphae 5-7.5 $\mu \mathrm{m}$ wide. Stipitipellis as cutis, compose of longitudinally orientated hyphae 3.8-5 $\mu \mathrm{m}$ wide, without caulocystidia. Volva with hyaline hyphae in $3 \% \mathrm{KOH}$; inner layer compose by interwoven hyphae 14-20 $\mu \mathrm{m}$ wide, thin-walled; outer layer composed by hyphae 6.3-8.8 $\mu \mathrm{m}$ wide, thin-walled. Clamp connections absent from all tissues examined.

Habitat - Solitary on clay soil in wet forest.

\section{Discussion}

Shaffer's (1957) key for Volvariella from North America separated species by size of the basidiospores, surface and size of the pileus and pileus, stipe and volva color and habitat. The species that can be most phenetically related to $V$. leucocalix is $V$. lepiotospora Singer, with 'radiately arranged brownish black to black fibrils except on the disc, brownish black on the disc' pileus and basidiospores 4.7-6(-7) $\times 3-3.7 \mu \mathrm{m}, \mathrm{Q}=1.52-1.95(\mathrm{Qm}=1.67)$; but differs in the gray volva, pleurocystidia with small vesicles and clavate cheilocystidia 21-26 × 7-9.6 $\mu \mathrm{m}$ (Shaffer 1957: 566).

Shaffer (1962) described V. nigrodisca Shaffer from North America similar to V. leucocalix with usually white volva, but differs by the black to brownish centre and gray toward the pileus margin, larger basidiospores 5.7-7.3 × 3.9-4.5 $\mu \mathrm{m}$, larger pleurocystidia 37-60 × 8-18.8 $\mu \mathrm{m}$, larger cheilocystidia $23-55 \times 8-16.9 \mu \mathrm{m}$, obovoid to broadly clavate or fusoid-ventricose, and 


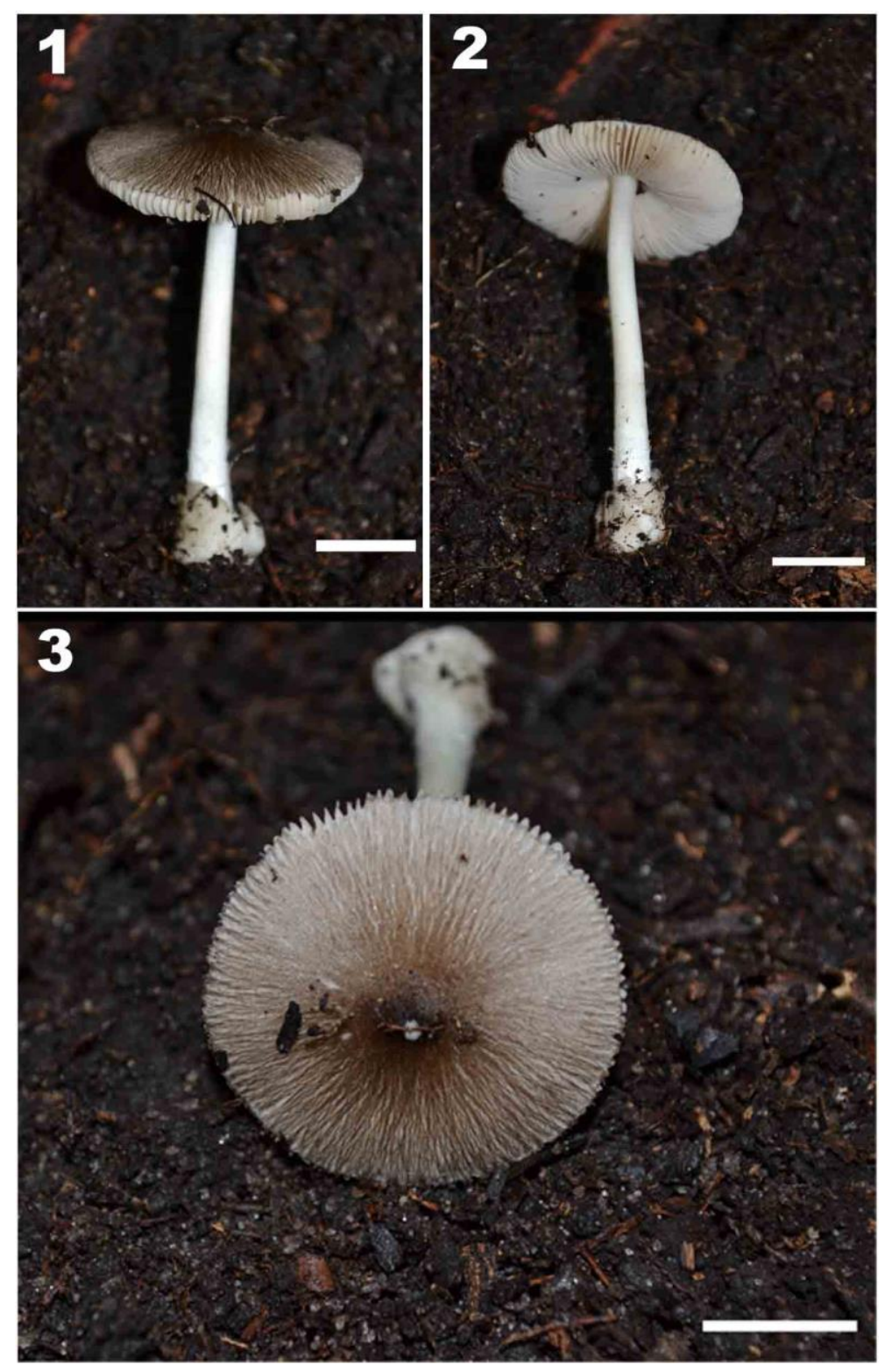

Figs 1-3 - Volvariella leucocalix (holotype). 1-2. Basidiome in side view. 3. pileus surface. Scale bars are $10 \mathrm{~mm}$.

pileipellis composed by radially orientated brownish hyphae 4-22.6 $\mu \mathrm{m}$ in diam. with terminal cells often cystidioid with refractive contents, 4-10.6 $\mu \mathrm{m}$ diam.

Later, Heinemann (1975) described $V$. parvispora Heinem., from Africa, also having fuliginous ("fuliginosus") pileus and white volva and somewhat similar basidiospores size (4.2) 4.5-5.7 $\times 3-4 \mu \mathrm{m}$. However it differs at least in the paler and more tomentose pileus, volva turning fuliginous and larger pleurocystidia $60-70 \times 12-16 \mu \mathrm{m}$. This description does not provide any other details about this species.

Volvariella heterospora Menolli \& Capelari from São Paulo also has dark pileus, whitish volva and similar size of the pleurocystidia (32-)37-49 $\times(6.2-) 7.5-10(-11.2) \mu \mathrm{m}$. However, this species has two different basidiospores sizes, $(6.4-) 7.2(-8) \times(4-) 4.8(-5.6) \mu \mathrm{m}$ and $(8.8-) 9.6-12(-$ 13.6) $\times(4.8-) 5.6-6.4 \mu \mathrm{m}$, obviously larger than our material. In addition, it was also protologued as having thinner volval elements compose of interwoven hyphae 3.7-7.5 $\mu \mathrm{m}$, hyaline, frequently not septate; lamellar trama with thin to slightly thick-walled hyphae 2.5-17.5 $\mu \mathrm{m}$ diam.; and pileipellis as trichoderm, up to $640 \mu \mathrm{m}$ thick, compose of hyphae 5-26 $\mu \mathrm{m}$ wide with brown content and erect to suberect terminal septate elements with light brown content (Menolli \& Capelari 2008). 

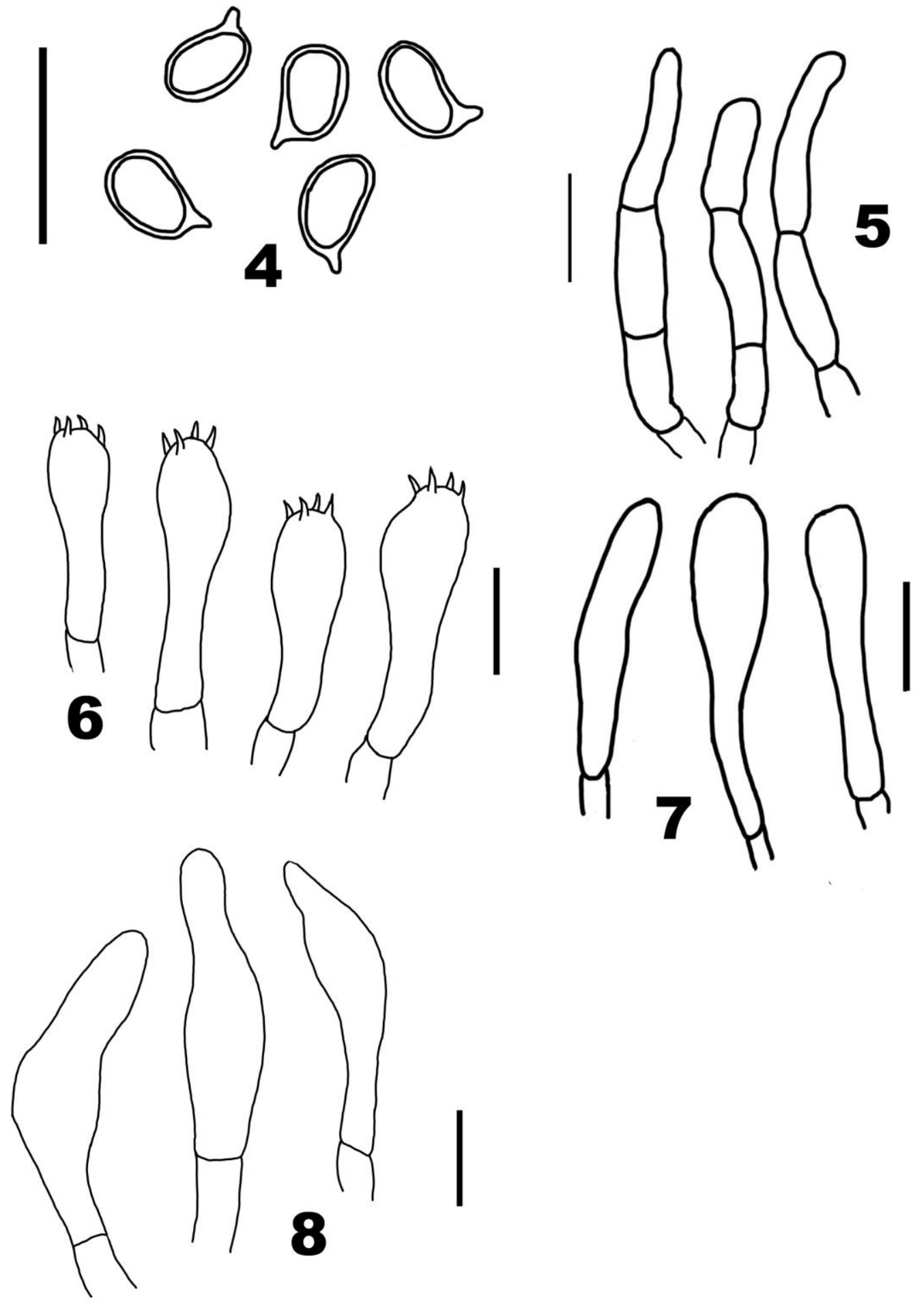

Figs 4-8 - Volvariella leucocalix. 4. Basidiospores. 5. Terminal elements of pileipellis. 6. Basidia. 7. Cheilocystidia. 8. Pleurocystidia. Scale bar $=10 \mu \mathrm{m}$.

Volvariella perciliata Courtec. from French Guiana is similar to V. leucocalix in small basidioma, darker pileus and white volva, but differs in the presence of ciliate teeth at pileus margin, larger basidiospores $7-8 \times 4-4.5 \mu \mathrm{m}$, larger cylindric to broadly ellipsoid pleurocystidia 45-75 $\times 7-12 \mu \mathrm{m}$; larger cheilocystidia 40-60 $\times 5-15 \mu \mathrm{m}$ that are rather slender lageniform but not with an abruptly contracted neck, stalked at some lengths; and the pileipellis as a slightly gelatinous trichoderm with some gray-brownish elements (Courtecuisse 1991). Menolli \& Capelari (2009) reported this taxon from Brazil and reported slightly longer basidiospores $(6.2-) 7.5-8.7(-10) \times$ (3.7-)5(-6.2) $\mu \mathrm{m}$. 
Volvariella dunensis (Vila, Àngel \& Llimona) Justo \& M.L. Castro also has a dark pileus and white volva, but differs from $V$. leucocalix by the larger basidiomata, the gray or bluish gray pileus, larger basidiospores 7-8.5 $\times 4.5-6 \mu \mathrm{m}$, larger, clavate and slightly utriform pleurocystidia (34-)50-95(-108) $\times(16-) 20-45(-50) \mu \mathrm{m}$, larger, clavate or utriform cheilocystidia 20-80 × 15-60 $\mu \mathrm{m}$; and pileipellis as a cutis (Justo \& Castro 2010).

Volvariella fibrillosa (Bres.ex Rick) Singer can be treated as a phenetically similar taxon. Although cited several times by Rick (1907, 1919, 1938), it was fully described only in Bresadola (1920) as 'Volvaria fibrillosa Bres. in Rick', who equivocally cited an illustration in the volume 5 of the journal 'Broteria Série Botânica'. Actually, the illustration was given in the volume 6 of this journal (Rick 1907). Also, there is no mention that 'Volvaria fibrillosa' is a new species in Rick (1907, p. 67) nor Bresadola (1920), only in the legend of the figure 5 of the plate 7 of Rick (1907). According to McNeill et al. (2012) in the Arts. 38.7-38.10, illustration with analysis is acceptable in place of a written description or diagnosis. However the illustration did not show sufficient details aiding species identification, only in the description given by Bresadola (1920), which clearly cannot be considered as a diagnosis. In our interpretation, for reasons given above, the name Volvariella fibrillosa is a nomen nudum and consequently unavailable for use. Saccardo \& Trotter (1912: 129) already stated that diagnosis in Rick (1907) is all incomplete.

\section{Acknowledgements}

The authors whish thank to Felipe G.B. Pinheiro for help in the collection of the new species, and to 'Programa de Pesquisa em Biodiversidade do Semi-árido' Project (CNPq Proc. 457476/2012-5) for providing funds for trip collections.

\section{References}

Andrade LA, Oliveira FX, Nascimento IS, Fabricante JR, Sampaio EVSB, Barbosa MRV. 2006 Análise florística e estrutural de matas ciliares ocorrentes em brejo de altitude no município de Areia, Paraíba. Revista Brasileira de Ciências Agrárias 1, 31-40.

Barbosa MRV, Agra MF, Sampaio EVSB, Cunha JP Andrade LA. 2004 - Diversidade florística na Mata do Pau-Ferro, Areia, Paraíba. In: Pôrto KC, Cabral JJP, Tabarelli M eds. Brejos de Altitude em Pernambuco e Paraíba. História Natural, Ecologia e Conservação. Brasília: Ministério do Meio Ambiente, 111- 122.

Batista AC. 1957 - Alguns Agaricales saprófitos de Pernambuco. Mycopathologia et Micologia Applicata 8, 127-134.

Bresadola G. 1920 - Selecta Mycologica. Annales Mycologici 18, 26-70.

Courtecuisse R. 1991 - Eléents pour inventaire mycologique des environs du saut Pararé (Arataye) et de l'inselberg des Nouragues (Guyane française). V. Pluteaceae. (Pluteales, Basidiomycota). Cryptogamic Botany 2/3, 136-152.

de Meijer AAR. 2001 - Mycological work in the Brazilian state of Paraná. Nova Hedwigia 72, $105-159$.

de Meijer AAR. 2006 - Preliminary list of the macromycetes from the Brazilian state of Paraná. Boletim do Museu Botânico Municipal Curitiba 68, 1-55.

Heinemann P. 1975 - Observations sur le genre Volvariella Speg. Bulletin du Jardin botanique national de Belgique 45, 185-193.

Justo A, Castro ML. 2010 - The genus Volvariella in Spain: V. dunensis comb. \& stat. nov. and observations in V. earlei. Mycotaxon 112, 261-270.

Justo A, Vizzini A, Minnis AW, Menolli Jr. N, Capelari M, Rodríguez O, Malysheva E, Contu M, Ghignone S, Hibbett DS. 2010 - Phylogeny of the Pluteaceae (Agaricales, basidiomycota): taxonomy and character evolution. Fungal Biology 115, 1-20.

McNeill J, Barrie FR, Buck WR, Demoulin V, Greuter W, Hawksworth DL, Herendeen PS, Knapp S, Marhold K, Prado J, Prud'homme van Reine WF, Smith GF, Wiersema JH, Turland NJ (eds.). 2012 - International Code of Nomenclature for algae, fungi, and plants (Melbourne 
Code): Adopted by the Eighteenth International Botanical Congress Melbourne, Australia, July 2011. Regnum Vegetabile 154. Königstein: Koeltz Scientific Books.

Menolli Jr. N, Capelari M. 2008 - Records and two new species of Volvariella (Pluteaceae, Agaricales) from Brazil. Mycotaxon 106, 385-398.

Oliveira FX, Andrade LA, Félix LP. 2006 - Comparações florísticas e estruturais entre comunidades de Floresta Ombrófila Aberta com diferentes idades, no Município de Areia, PB, Brasil. Acta Botanica Brasilica 20, 861-873.

Putzke J. 1994 - Lista dos fungos Agaricales (Hymenomycetes, Basidiomycotina) referidos para Brasil. Caderno de Pesquisa Série Botânica 6, 1-189.

Rick J. 1907 - Contributio ad monographiam Agaricacearum et Polyporacearum Brasiliensium. Brotéria Série Botânica 6, 65-92.

Rick J. 1919 - Contributio II ad monographiam Agaricacearum Brasiliensium. Brotéria Série Botânica 17, 101-111.

Rick J. 1920 - Contributio III ad monographiam Agaricacearum Brasiliensium. Brotéria Série Botânica 18, 48-63.

Rick J. 1938 - Agarici Riograndenses. Lilloa 2, 251-316.

Saccardo PA, Trotter A. 1912 - Hymenomycetae-Phycomycetae. Sylloge Fungorum 21 (Supplementum Universale Pars VIII), 1-928.

Shaffer RL. 1957 - Volvariella in North America. Mycologia 49, 545-579.

Shaffer RL. 1962 - Synonyms, new combinations, and new species in Volvariella (Agaricales). Mycologia 54, 563-572.

Singer R. 1953 - Type studies on basidiomycetes VI. Lilloa 26, 57-159.

Singer R. 1986 - The Agaricales in modern taxonomy. 4 ed. Koeltz Scientific Books, Koenigstein: Germany.

Singer R. 1989 - New taxa and new combinations of Agaricales (Diagnosis Novorum Agaricalium IV). Fieldiana, Botany 21, 1-133.

Sobestiansky G. 2005 - Contribution to a macromycete survey of the States of Rio Grande do Sul and Santa Catarina in Brazil. Brazilian Archives of Biology and Technology 48, 437-457.

Theissen F. 1912 - Hymenomycetes Riograndenses. Brotéria Série Botânica 10, 5-28.

Wartchow F. 2009 - Volvariella cubensis: a rare neotropical agaric new to South America. Mycotaxon 107, 181-187. 